\title{
PHAGE DISPLAY - A TOOL FOR DETECTION AND PREVENTION AGAINST PATHOGENS. A REVIEW
}

\author{
BARBORA VIDOVÁ ${ }^{1,2}$, ANDREJ GODÁNY ${ }^{2}$, ERNEST ŠTURDÍK ${ }^{1}$ \\ ${ }^{1}$ Institute of Biochemistry, Nutrition and Health, Slovak University of Technology, \\ SK-812 37 Bratislava, Slovak Republic (b.vidova@gmail.com) \\ ${ }^{2}$ Institute of Molecular Biology, Slovak Academy of Sciences \\ SK-845 51, Bratislava, Slovak Republic \\ ${ }^{3}$ Department of Biotechnology, University of SS. Cyril and Methodius, \\ SK-917 01 Trnava, Slovak Republic
}

\begin{abstract}
In this article are reviewed the promising uses of phage display in the areas such as microbial pathogens detection of and vaccination. Phage display is a molecular technique by which foreign proteins are expressed at the surface of phage particles. Such phages thereby become vehicles for expression that not only carry within them the nucleotide sequence encoding expressed proteins, but have also the capability to replicate. Recent data acquired from genome sequencing and advances in phage biology research have aided the development of phage-derived bacterial detection and treatment strategies.
\end{abstract}

Key words: phage display, microbial pathogens, detection

\section{Introduction}

Bacteriophages (phages) are viruses that infect bacteria. Phages are either virulent (lytic) or temperate and use the host bacterium as a factory for their own replication. Since their independent discovery by Twort and d'Herelle, research on phage has enabled major fundamental and technological advances that have been essential for the emergence of modern molecular biology (MCAULIFFE et al., 2007). In fact, it is difficult to over-emphasize the large impact that phage research has had on molecular biology. For example, phage research was cardinal in defining the central dogma of molecular biology, in the identification of DNA as the genetic material, the definition and mapping of the gene, and the discovery of mRNA as an intermediate for the production of proteins. Furthermore, phages were used, simply and elegantly, to demonstrate the random pre-existing nature of genetic mutations before evolutionary selection, providing clear evidence of Darwin's natural selection theory (CAIRNS et al., 2006). Our understanding of gene regulation has also profited immensely from studies using lambda phage $(\lambda)$ (PTASHNE, 2004). In molecular biology, the impact of phage-derived technology is clearly visible: transducing phage, restriction enzymes, phage promoter-based expression systems, random mutagenesis (e.g. phage $\mathrm{Mu}$ ), phage-based cloning vectors and genomic libraries, and phage display techniques, to name but a few. The sheer abundance of phage on Earth (estimated to be 1031 (WOMMACK and COLWELL, 2000)) and the accumulating data from both phage and bacterial genome sequencing projects have highlighted the global significance of phage in bacterial ecosystems and their key role in the adaptive evolution of bacteria. 
Sequence analysis indicates that up to $20 \%$ of each bacterial genome might consist of phage-related DNA in the form of prophage or phage remnants (CASJENS, 2003). The importance of these phage-related sequences in the evolution of bacteria is most striking in the phenomenon of lysogenic conversion. For example, in Vibrio cholerae, the genes encoding cholera toxin are provided by a converting phage, resulting in a virulent strain (WALDOR and FRIEDMAN, 2005). Phage are genetically diverse; approximately half of newly sequenced phage genes have no known homologues (HAMBLY and SUTTLE, 2005), and phage genomes vary in size by at least two orders of magnitude (KUTTER, 2005).

This review aims to provide an insight into how an understanding of phage biology can be exploited to generate novel bacterial detection and vaccination strategies.

\section{Phage display principles}

In phage display, a heterologous peptide or protein is displayed on the surface of the phage (Fig. 1) through transcriptional fusion with a coat-protein gene (SMITH, 1985), which is accomplished by the incorporation of the nucleotide sequence encoding the protein to be displayed into a phage or phagemid genome as a fusion to a gene encoding a phage coat protein. This fusion ensures that as phage particles are assembled, the protein to be displayed is presented at the surface of the mature phage, while the sequence encoding it is contained within the same phage particle. This physical link between the phenotype and genotype of the expressed protein and the replicative capacity of phage are the structural elements that underpin all phage display technology (Fig. 1) (WILLATS, 2002).

This results in a production a novel phage particle that has a variety of potential uses. The most widely used phage display methods are based on the use of M13 and related filamentous phages of Escherichia coli but others, including the E. coli phages $\lambda$ and T7, have also been used (BENHAR, 2001, WILLATS, 2002). Because particulate phages are relatively easy and inexpensive to purify, phage display can also provide a means of purifying a particular protein or antibody. Phage-display libraries can be screened in several ways to isolate displayed peptides or proteins with practical applications. For example, it is possible to isolate displayed peptides that bind target proteins with affinities similar to those of antibodies. They can then be used as therapeutics, which act either as agonists or through the inhibition of receptor-ligand interactions.

The high-affinity, displayed peptides also have the potential to be used for the detection of pathogens and agents posing a biological threat in the environment (PETRENKO and VODYANOY, 2003). A more complete discussion of the potential of phage display is given in several recent reviews (BENHAR, 2001, WILLATS, 2002, WANG and YU, 2004).

The simplest way of achieving the expression of a foreign protein is to simply create a fusion between the nucleotide sequence to be expressed and a coat protein gene within the viral genome (Fig. 2a).

Using this direct approach all the copies of the chosen coat protein become fusion proteins (WINTER et al. 1994). This can be advantageous in terms of numbers of 
expressed foreign proteins but if the functionality of the chosen coat protein is compromised by the fusion then phage viability may be affected, especially since no wild type versions of the coat protein are retained.

(a)

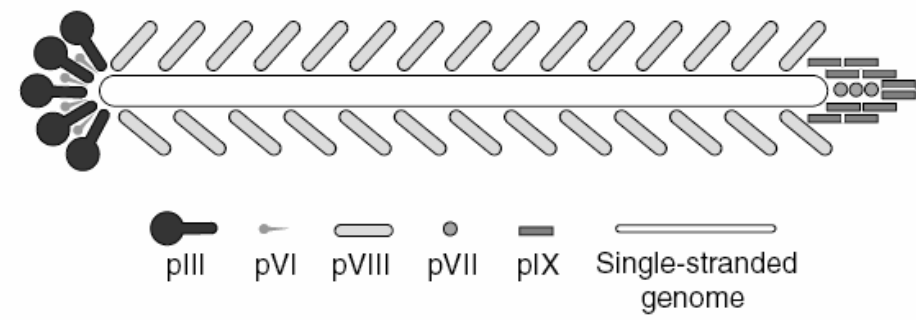

(b)

plll display

(c)

pVIII display

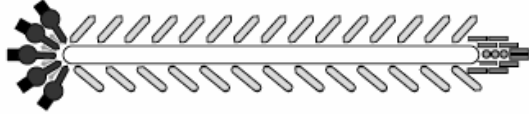

Full

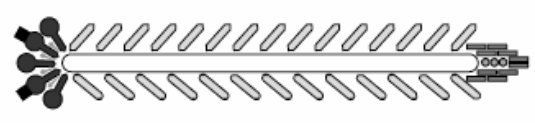

Hybrid

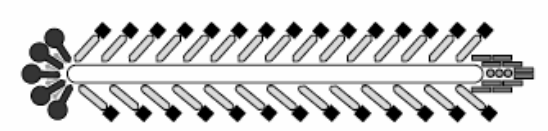

Full

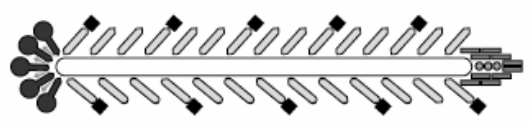

Hybrid

- Foreign peptide or protein

Current Opinion in Chemical Biology

Fig. 1. The principle of phage display. (a) Simplified hypothetical bacteriophage with coat proteins pIII, pVI, pVIII, pVII, pIX. (b) Forein peptide or protein is dispalyed at the phage surface by the fusion of gene encoding forein protein with phage pIII coat protein coding gene, or (c) by the fusion of gene encoding forein protein with phage $\mathrm{pVIII}$ coat protein coding gene. The number of copies of forein protein displayed is related to which phage coat protein is chosen as a fusion partner (MELITA et al., 2001).

This can be avoided if hybrid phages are produced in which some versions of a given coat protein are wild type and some are fused to a foreign protein (Fig. 2b and 2c). In some hybrid phage systems, the gene fusion is an additional element of the phage genome so that a wild type copy of the coat protein gene is retained and phage particles express both wild type and fusion proteins (Fig. 2b) (SIDHU, 2001).

Alternatively, hybrid phage may be created using a phagemid-based system and this approach has been widely adopted (Fig. 2c). Sequences encoding fusion proteins are carried by phagemids (plasmids with a phage origin of replication) while the most of the genes required for the formation of phage particles are carried by helper phage that is co-infected together with phagemids into host bacteria (SIDHU, 2001) (Fig. 2c). 


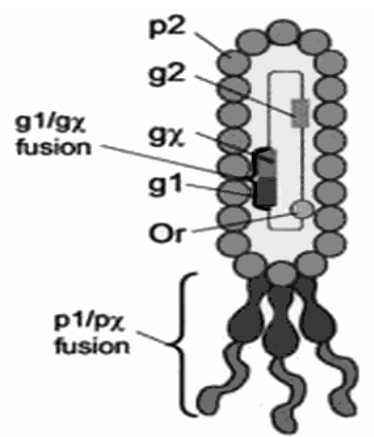

(a)
Phage

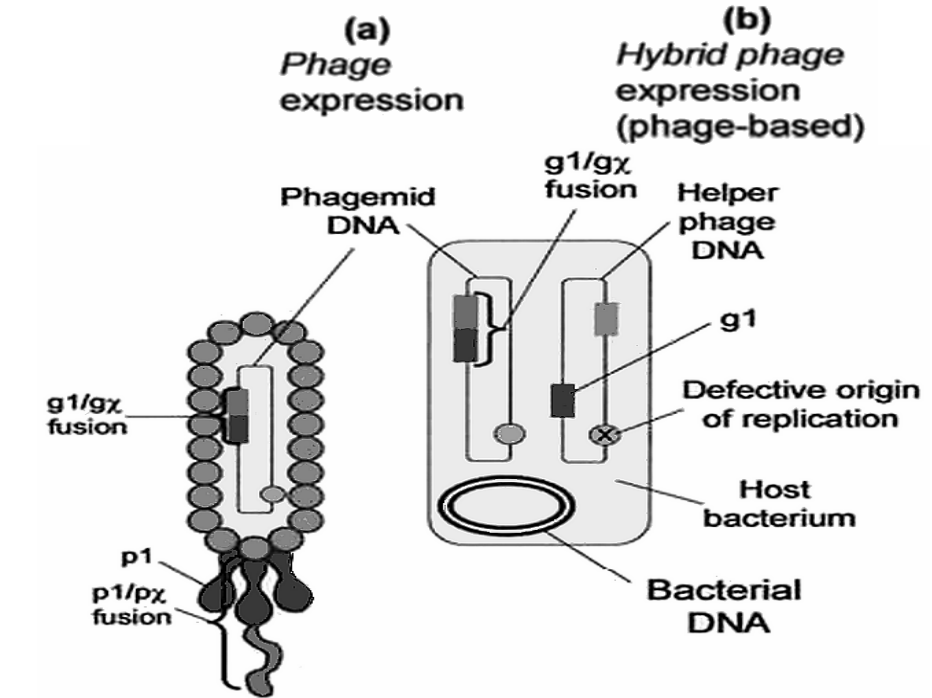

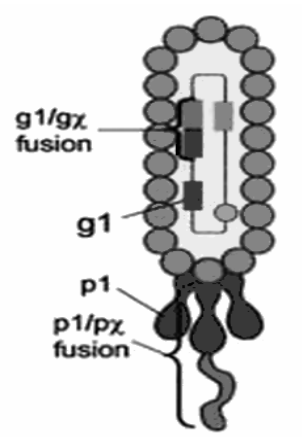

(b)

Hybrid phage

expression

(phage-based)

(c)

Hybrid phage

expression

(phagmid-based)

Plant Molecular Bjology

Fig. 2. Strategies for the expression of proteins at the surface of a simplified hypothetical bacteriophage. The simplest format for the expression of a peptide or protein (a) is to fuse the gene $(\mathrm{g} \gamma)$ encoding the foreign protein ( $\mathrm{p} \chi$ ) to one of the phage coat protein genes (e.g., g1) Hybrid phage (b) may be created by incorporating the gene fusion $(\mathrm{g} / \mathrm{g} \chi)$ as an additional element in the phage genome. With this arrangement, two versions of the phage coat protein chosen as the fusion partner are encoded - one by the native gene ( $\mathrm{p} 1)$ and one by the fusion gene $(\mathrm{p} 1 / \mathrm{p} \chi)$. As phage particles are assembled both $\mathrm{p} 1$ and $\mathrm{p} 1 / \mathrm{p} \chi$ are incorporated into the phage coat. Phagemid based systems (c) are also widely used to construct hybrid phage. However, instead of being present on a single genome, the genes encoding wild type coat protein and fused protein are carried by helper phage and phagemid respectively. Host bacteria contain both phagemid and helper phage DNA and both genomes contribute to the synthesis of hybrid phage particles (WILLATS, 2002).

\section{Phages for the detection and typing of bacteria}

Many methods of detecting specific bacteria are available, but the low-cost and ready production of large numbers of phage, added to their specificity for a target 
bacterial species, makes them ideal for bacterial detection. Although other biomolecules can confer specificity of molecular recognition, they have their own limitations. For example, antibodies are expensive to produce and sensitive to harsh environmental conditions. Another important advantage of phage-based systems is that they usually only detect living bacteria, thereby reducing the number of false positives that arise from the use of approaches such as PCR. Furthermore, dead cells present after processes such as pasteurization or disinfection might be no hazardous but still can be detected by antibodies (PETTY et al., 2007).

Phages bounded to bacteria can be detected by specific labeled antibodies, thereby increasing the sensitivity of detection (WATSON and EVELAND, 1965). For specific typing, different species of phage can be plated out onto a lawn comprising an unidentified bacterial strain, and the presence of clear areas (plaques) where an individual phage particle has grown and lysed the surrounding cells enables identification of the specific bacteria. Recombinant phages are often used in phagebased detection systems (BENHAR, 2001; WILLATS, 2002). The methods that have been used to detect pathogenic bacteria include (i) using phages specifically to deliver reporter genes, e.g. lux (KODIKARA et al., 1991) or green fluorescent protein (FUNATSU et al., 2002), which are expressed after infection of target bacteria; (ii) using phages that have a fluorescent dye covalently attached to the phage coat, and detecting the specific adsorption (HENNES et al., 1995; GOODRIDGE et al., 1999); (iii) the detection of released cellular components, such as adenylate kinase (CORBITT et al., 2000), after specific lysis; and (iv) using phages displaying peptides or antibody fragments that will bind specific bacterial pathogens or toxins. Other means of improving the sensitivity of detection are phage amplification assays. In brief, phage infection of the pathogenic bacterium results in the release of many phage particles that can be detected by a second (non-pathogenic), sensitive bacterial strain. Success with this approach has been seen with the detection of Mycobacterium tuberculosis (PETRENKO and VODYANOY, 2003). A more detailed account of these and other techniques is provided elsewhere (KUTTER, 2005) and a selection that emphasizes the range and sensitivity of the technologies used and the diversity of detectable bacterial species is summarized in Table 1 (PETTY et al., 2007).

\section{Phages as vaccine delivery vehicles}

Phages have been used as potential vaccine delivery vehicles in two different ways: by directly vaccinating with phages carrying vaccine antigens on their surface or by using the phage particle to deliver a DNA vaccine expression cassette that has been incorporated into the phage genome (CLARK and MARCH, 2004).

In phage-display vaccination, phages can be designed to display a specific antigenic peptide or protein on their surface. Alternatively, phages displaying peptide libraries can be screened with a specific antiserum to isolate novel protective antigens or mimetopes - peptides that mimic the secondary structure and antigenic properties of a protective carbohydrate, protein or lipid, despite having a different primary structure (FOLGORI et al., 1994; PHALIPON et al., 1997). The serum of convalescents can also be used to screen phage-display libraries to identify potential vaccines against 
a specific disease, without prior knowledge of protective antigens (MEOLA et al., 1995). In a few cases, whole phage particles displaying antigenic proteins have been used as vaccines in animal models (WANG and YU, 2004; IRVING et al., 2001). Specific antibody responses (DI MARZO VERONESE et al., 1994) and protection against an immune challenge have been shown (BASTIEN et al., 1997).

Tab. 1. Applications of the different phage-based antibacterial strategies

\begin{tabular}{|c|c|c|c|c|c|}
\hline Target species & Type of assay & Matrix & $\begin{array}{l}\text { Assay } \\
\text { time } \\
\text { (hours) }\end{array}$ & Sensitivity & Refs \\
\hline \multirow[t]{2}{*}{$\begin{array}{l}\text { Listeria } \\
\text { monocytogenes }\end{array}$} & $\begin{array}{l}\text { luxAB reporter phage } \\
\text { and single-tube }\end{array}$ & Culture & 2 & $\begin{array}{l}10^{2}-10^{3} \\
\mathrm{cfu} / \mathrm{ml}\end{array}$ & $\begin{array}{l}\text { LOESSNER } \text { et } \\
\text { al., } 1996\end{array}$ \\
\hline & luminometer & Spiked salad & $22-24$ & $1 \mathrm{cfu} / \mathrm{g}$ & \\
\hline \multirow[t]{2}{*}{ E. coli 0157:H7 } & $\begin{array}{l}\text { Fluorescently labeled } \\
\text { phage and flow }\end{array}$ & Ground beef & 6 & $2.2 \mathrm{cfu} / \mathrm{g}$ & $\begin{array}{l}\text { GOODRIDGE } \\
\text { et al., } 1999\end{array}$ \\
\hline & cytometry & Milk & 10 & $\begin{array}{l}10^{1}-10^{2} \\
\mathrm{cfu} / \mathrm{ml}\end{array}$ & \\
\hline \multirow[t]{4}{*}{$\begin{array}{l}\text { E. coli XL1- } \\
\text { Blue }\end{array}$} & $\begin{array}{l}\text { Quorum sensing and } \\
\text { bioluminescence }\end{array}$ & Culture & 1.5 & $10^{8} \mathrm{cfu} / \mathrm{ml}$ & $\begin{array}{l}\text { RIPP et al., } \\
2006\end{array}$ \\
\hline & (luxCDABE) & & 10.3 & $1 \mathrm{cfu} / \mathrm{ml}$ & \\
\hline & & Spiked lettuce & 12.1 & $10^{5} \mathrm{cfu} / \mathrm{ml}$ & \\
\hline & & leaves & 22.4 & $10^{2} \mathrm{cfu} / \mathrm{ml}$ & \\
\hline \multirow[t]{2}{*}{ E. coli BL-21 } & $\begin{array}{l}\text { Biotin-tagged phage } \\
\text { and quantum dots } \\
\text { nanocomplexes, } \\
\text { fluorescence } \\
\text { microscopy }\end{array}$ & Culture & 1 & $10 \mathrm{cfu} / \mathrm{ml}$ & $\begin{array}{l}\text { EDGAR et al., } \\
2006\end{array}$ \\
\hline & and flow cytometry & & & & \\
\hline $\begin{array}{l}\text { Pseudomonas } \\
\text { aeruginosa }\end{array}$ & Phage amplification & Culture & 4 & $40 \mathrm{cfu} / \mathrm{ml}$ & $\begin{array}{l}\text { STEWART et } \\
\text { al., } 1998\end{array}$ \\
\hline E. coli & $\begin{array}{l}\text { Phage-mediated } \\
\text { release of adenylate }\end{array}$ & Culture & 1 & $10^{4} \mathrm{cfu} / \mathrm{ml}$ & $\begin{array}{l}\text { BLASCO et al., } \\
1998\end{array}$ \\
\hline & kinase & & & & \\
\hline $\begin{array}{l}\text { Mycobacteriu } \\
\text { m tuberculosis }\end{array}$ & $\begin{array}{l}\text { Phage replication } \\
\text { assay }\end{array}$ & Sputum & 2 days & $100 \mathrm{cfu} / \mathrm{ml}$ & $\begin{array}{l}\text { MCNERNEY et } \\
\text { al., } 2004\end{array}$ \\
\hline $\begin{array}{l}\text { Microlunatus } \\
\text { phosphovorus }\end{array}$ & $\begin{array}{l}\text { Fluorescently labelled } \\
\text { phage and } \\
\text { epifluorescent } \\
\text { microscopy }\end{array}$ & Activated sludge & 1 & $10^{2} \mathrm{cfu} / \mathrm{ml}$ & LEE et al., 2006 \\
\hline $\begin{array}{l}\text { E. coli K-12, } \\
\text { MG1655 }\end{array}$ & $\begin{array}{l}\text { b-D-galactosidase } \\
\text { reporter phage and } \\
\text { amperometric } \\
\text { detection }\end{array}$ & Culture & $6-8$ & $\begin{array}{l}0.01 \\
\mathrm{cfu} / \mathrm{ml}\end{array}$ & $\begin{array}{l}\text { NEUFELD et } \\
\text { al., } 2003\end{array}$ \\
\hline $\begin{array}{l}\text { E. coli K-12 } \\
\text { W3110 }\end{array}$ & $\begin{array}{l}\text { SEnsing of Phage- } \\
\text { Triggered Ion Cascade } \\
\text { (SEPTIC) }\end{array}$ & Culture & $10 \mathrm{~min}$ & $1 \mathrm{cfu} / \mathrm{ml}$ & $\begin{array}{l}\text { DOBOZI-KING } \\
\text { et al., } 2005\end{array}$ \\
\hline $\begin{array}{l}\text { Staphylococcu } \\
\text { s aureus }\end{array}$ & $\begin{array}{l}\text { SPREETA surface } \\
\text { plasmon resonance }\end{array}$ & Culture & Not stated & $10^{4} \mathrm{cfu} / \mathrm{ml}$ & $\begin{array}{l}\text { BALASUBRA } \\
\text { MANIAN et al., } \\
2006\end{array}$ \\
\hline
\end{tabular}


Rather than generating a transcriptional fusion to a coat protein, substances could also be artificially conjugated to the surface of phages after growth, which further increases the range of antigens that can be displayed (MOLENAAR et al., 2002). Because phage particles are naturally immunostimulatory (CLARK and MARCH, 2004; KLEINSCHMIDT et al., 1970), an antigen presented on the phage coat would come 'ready conjugated' with a natural adjuvant activity, without the need for separate protein purification and subsequent conjugation to a carrier molecule before immunization. More recently, it has also been shown that unmodified phages can be used to deliver DNA vaccines more efficiently than standard plasmid DNA vaccination (CLARK and MARCH, 2004; MARCH et al., 2004; JEPSON and MARCH, 2004). When compared with standard DNA vaccination, superior antibody responses have been shown in mice (CLARK and MARCH, 2004) and rabbits (MARCH et al., 2004).

\section{Conclusion}

According to here reviewed information about phage display, this technique/tool has a multipurpose utilization in molecular evolution, analysis of protein/ligand interactions and the generation of antibodies. Taking into account a prevention against pathogenic microorganisms, phage display could be used as a potential vaccine against Streptococcus agalactiae, a well-known bovine mastitis pathogen of particular importance because it is highly infectious (spreading from cow to cow by machine milking, unless care is taken to disinfect the teat cups), and causes mainly subclinical infections. As a result, S. agalactiae can spread widely within a herd, causing immediate loss due to reduced milk yield, and eventual large losses, when it is finally recognized. Additionally, this pathogen can be transmitted through dairy product to consumers. Therefore, useful vaccine against this bacterium is of great interest. All clinical isolates of $S$. agalactiae express a polysaccharide capsule, with nine capsular serotypes identified so far. The major invasive disease causing serotypes are Ia, Ib, II, and III (SCHUCHAT, 1998). Indeed, it was observed that the protection conferred by capsular polysaccharides is type specific (KASPER et al., 1996). Noncapsular surface antigens are being investigated as potential vaccine candidates or carrier proteins (GRAVEKAMP et al., 1999; STÅLHAMMAR-CARLEMALM et al., 1993). One of these noncapsular antigens, the Sip protein, was highly conserved and produced by every $S$. agalactiae strain examined to date, which included representative isolates of all serotypes (BRODEUR et al., 2000; CHOTÁR et al., 2006). It was also established that Sip-specific antibodies recognized their epitopes at the cell surfaces of different $S$. agalactiae strains (RIOUX et al., 2001). More importantly, the immune response to purified recombinant Sip protein efficiently protected adult mice against experimental infection with $S$. agalactiae strains representing serotypes Ia/c, Ib, II/R, III, V, and VI (BRODEUR et al., 2000). However, the direct use of a peptide presenting by a recombinant phage displaying as a vaccine to examine its protective potential would be simpler and much less expensive than the conventional method of peptide synthesis or recombinant protein preparation and purification for immunization.

The recombinant phage displaying a pathogen specific peptide, in S. agalactiae the displaying of mentioned Sip protein or its part, representing an immunogenic mimic of 
natural antigen. This could lead to production of antibodies specific to pathogen. Recombinant bacteriophage displaying a disease specific epitope can be use as a vaccine to examine the potential of an epitope of interest to prevent disease. Phage display has also the overwhelming advantage that it is has cheap and easy. It uses standard microbiological techniques that are familiar to all molecular biologists, and its key resources - phage libraries and clones - are replicable and therefore nearly costfree after their initial construction or selection. It is astonishing to contemplate that within a single tube could be fit a few hundred trillion phage particles displaying billions of different peptide structures - an abundance and diversity from which hundreds of different users with altogether different purposes in mind can select clones of great value. And when that supply has nearly run out, only simple propagation is needed to replenish what is left to satisfy the needs.

Where a safe and efficacious vaccine available, screening and administration of antibiotics would be unnecessary, policies for the prevention of $S$. agalactiae infections would be simplified and importantly, prevention would be more successful, whereby this approach is applicable to many other pathogenic microorganisms. Additionally, cost-effectiveness analyses invariably demonstrate that vaccination is the most cost-effective of all potential prevention.

Acknowledgements: Figure 1 has been reprinted from Current Opinion in Chemical Biology, Vol 5, Melita, B., Irving, M.B., Pan, O., Scott, J., Random-peptide libraries and antigenfragment libraries for epitope mapping and the development of vaccines and diagnostics, Pages No. 314-324, Copyright (2001), with permission from Elsevier. Figure 2 has been reprinted from Plant Molecular Biology, Vol 50, Willats, W.G.T., Phage display: practicalities and prospects, Pages No. 837-854, Copyright (2002), with permission from Elsevier.

\section{References}

BALASUBRAMANIAN, S., SOROKULOVA, I.B., VODYANOY, V.J., SIMONIAN, A.L.: Lytic phage as a specific and selective probe for detection of Staphylococcus aureus - a surface plasmon resonance spectroscopic study. Biosens. Bioelectron., 22, 2006, 948-955.

BASTIEN, N., TRUDEL, M., SIMARD, C.: Protective immune responses induced by the immunization of mice with a recombinant bacteriophage displaying an epitope of the human respiratory syncytial virus. Virology, 234, 1997, 118-122.

BENHAR, I.: Biotechnological applications of phage and cell display. Biotechnol. Adv., 19, 2001, 1-33.

BLASCO, R., MURPHY, M.J., SANDERS, M.F., SQUIRRELL, D.J.: Specific assays for bacteria using phage mediated release of adenylate kinase. J. Appl. Microbiol., 84, 1998, 661-666.

BRODEUR, B. R., BOYER, M., CHARLEBOIS, I., HAMEL, J., COUTURE, F., RIOUX, C. R., MARTIN, D.: Identification of group B streptococcal Sip protein, which elicits cross-protective immunity. Infect. Immun., 68, 2000, 5610-5618.

CAIRNS, J.A. STENT, G.S., WATSON, J.D.: Phage and the Origins of Molecular Biology, Cold Spring Harbor Laboratory, New York, 2006, 366 pp. 
CASJENS, S.: Prophages and bacterial genomics: what have we learned so far? Mol. Microbiol., 49, 2003, 277-300.

CLARK, J.R., MARCH, J.B.: Bacterial viruses as human vaccines? Expert Rev. Vaccines, 3, 2004, 463-476.

CORBITT, A.J., BENNION, N., FORSYTHE, S.J.: Adenylate kinase amplification of ATP bioluminescence for hygiene monitoring in the food and beverage industry. Lett. Appl. Microbiol., 30, 2000, 443-447.

Di MARZO VERONESE, F.,WILLIS, A.E., BOYER-THOMPSON, C., APPELLA, E., PERHAM, R.N.: Structural mimicry and enhanced immunogenicity of peptide epitopes displayed on filamentous bacteriophage. The V3 loop of HIV-1 gp120. J. Mol. Biol., 243, 1994, 167-172.

DOBOZI-KING, SEO, M.S., KIM, J.U., YOUNG, R., CHENG, M., KISH, L.B.: Rapid detection and identification of bacteria: SEnsing of Phage-Triggered Ion Cascade (SEPTIC). J. Biol. Phys. Chem., 5, 2005, 3-7.

EDGAR, R., MCKINSTRY, M., HWANG, J., OPPENHEIM, A.B., FEKETE, R.A., GIULIAN, G., MERRIL, C., NAGASHIMA, K., ADHYA, S.: High-sensitivity bacterial detection using biotintagged phage and quantum-dot nanocomplexes. Proc. Natl. Acad. Sci. U.S.A., 103, 2006, 4841-4845

FOLGORI, A., TAFI, R., MEOLA, A., FELICI, F., GALFRÉ, G., CORTESE, R., MONACI, P., NICOSIA, A.: A general strategy to identify mimotopes of pathological antigens using only random peptide libraries and human sera. EMBO J., 13, 1994, 2236-2243.

FUNATSU, T., TANIYAMA, T., TAJIMA, T., TADAKUMA, H., NAMIKI, H.: Rapid and sensitive detection method of a bacterium by using a GFP reporter phage. Microbiol. Immunol., 46, 2002, 365-369.

GOODRIDGE, L., CHEN, J., GRIFFITHS, M.: Development and characterization of a fluorescent-bacteriophage assay for detection of Escherichia coli O157:H7. Appl. Environ. Microbiol., 65, 1999, 1397-1404

GOODRIDGE, L., CHEN, J., GRIFFITHS, M.: The use of a fluorescent bacteriophage assay for detection of Escherichia coli $\mathrm{O} 157: \mathrm{H} 7$ in inoculated ground beef and raw milk. Int. J. Food Microbiol.. 47, 1999, 43-50.

GRAVEKAMP, C., KASPER D. L., PAOLETTI L. C., MADOFF L. C.: Alpha C protein as a carrier for type III capsular polysaccharide and as a protective protein in group B streptococcal vaccines. Infect. Immun., 67, 1999, 2491-2496.

HAMBLY, E., SUTTLE, C.A.: The viriosphere, diversity, and genetic exchange within phage communities. Curr. Opin. Microbiol., 8, 2005, 444-450.

HENNES, K.P. SUTTLE, C.A., CHAN, A.M.: Fluorescently labeled virus probes show that natural virus populations can control the structure of marine microbial communities. Appl. Environ. Microbiol., 61, 1995, 3623-3627.

JEPSON, C.D. MARCH, J.B.: Bacteriophage lambda is a highly stable DNA vaccine delivery vehicle. Vaccine, 22, 2004, 2413-2419.

KASPER, D. L., PAOLETTI, L. C., WESSELS, M. R., GUTTORMSEN, H.-K., CAREY, V. J.: Immune response to type III group B streptococcal polysaccharidetetanus toxoid conjugate vaccine. J. Clin. Investig., 98, 1996, 2308-2314. 
KLEINSCHMIDT, W.J. DOUTHART, R.J., MURPHY, E.B.: Interferon production by T4 coliphage. Nature, 228, 1970, 27-30.

KODIKARA, C.P., CREW, H.H., STEWART, G.S.: Near on-line detection of enteric bacteria using lux recombinant bacteriophage. FEMS Microbiol. Lett., 67, 1991, 261-265.

KUTTER, E.: Bacteriophages: Biology and Applications, CRC Press, Boca Raton, $2005,510 \mathrm{pp}$.

LEE, S.H., ONUKI, M., SATOH, H., MINO, T.: Isolation, characterization of bacteriophages specific to Microlunatus phosphovorus and their application for rapid host detection. Lett. Appl. Microbiol., 42, 2006, 259-264.

LOESSNER, M.J., REES, C.E., STEWART, G.S., SCHERER, S.: Construction of luciferase reporter bacteriophage A511: luxAB for rapid and sensitive detection of viable Listeria cells. Appl. Environ. Microbiol., 62, 1996, 1133-1140.

MARCH, J.B., CLARK, J.R., JEPSON, C.D.: Genetic immunization against hepatitis B using whole bacteriophage lambda particles. Vaccine, 22, 2004, 1666-1671.

MCAULIFFE, O., ROSS R.P., FITZGERALD, G.F.: The New Phage Biology: From Genomics to Applications. In: S. MCGRATH, D. VAN SINDEREN (Eds.) Bacteriophage: Genetics and Molecular Biology. Caister Academic Press, Norfolk, 2007, 1-43.

MCNERNEY, R., KAMBASHI, B.S., KINKESE, J., TEMBWE, R., GODFREYFAUSSETT, P.: Development of a bacteriophage phage replication assay for diagnosis of pulmonary tuberculosis. J. Clin. Microbiol., 42, 2004, 2115-2120.

MELITA, B., IRVING, M.B., PAN, O., SCOTT, J.: Random-peptide libraries and antigenfragment libraries for epitope mapping and the development of vaccines and diagnostics. Curr. Opin. Chem. Biol., 5, 2001, 314-324.

MEOlA, A., DELMASTRO, P., MONACI, P., LUZZAGO, A., NICOSIA, A., FELICI, F., CORTESE, R., GALFRE, G.: Derivation of vaccines from mimotopes. Immunologic properties of human hepatitis $\mathrm{B}$ virus surface antigen mimotopes displayed on filamentous phage. J. Immunol., 154, 1995, 3162-3172.

MOLENAAR, T.J., MICHON, I., DE HAAS, S.A., VAN BERKEL, T.J., KUIPER, J., BIESSEN, E.A.: Uptake and processing of modified bacteriophage M13 in mice: implications for phage display. Virology, 293, 2002, 182-191.

NEUFELD, T., SCHWARTZ-MITTELMANN, A., BIRAN, D., RON, E.Z., RISHPON, J.: Combined phage typing and amperometric detection of released enzymatic activity for the specific identification and quantification of bacteria. Anal. Chem., 75, 2003, 580-585.

PETRENKO, V.A., VODYANOY, V.J.: Phage display for detection of biological threat agents. J. Microbiol. Methods, 53, 2003, 253-262.

PETROVSKI, K.R., TRAJCEV, M., BUNESKI, G.: A review of the factors affecting the costs of bovine mastitis. J. S. Afr. Vet. Assoc., 77, 2006, 52-60.

PETTY, N.K., EVANS, T.J., FINERAN, P.C., SALMOND, G.P.C.: Biotechnological exploitation of bacteriophage research. Trends Biotech., 25, 2007, 7-15.

PHALIPON, A., FOLGORI, A., ARONDEL, J., SGARAMELlA, G., FORTUGNO, P., CORTESE, R., SANSONETTI, P.J., FELICI, F.: Induction of anti-carbohydrate antibodies by phage library-selected peptide mimics. Eur. J. Immunol., 27, 1997, 2620-2625. 
PTASHNE, M.: Genetic Switch: Phage Lambda Revisited, Cold Spring Harbor Laboratory Press, New York, 2004, 154 pp.

RIOUX, S., MARTIN D., ACKERMANN H.-W., DUMONT J., HAMEL J., BRODEUR B.R.: Localization of surface immunogenic protein on group B Streptococcus. Infect. Immun., 69, 2001, 5162-5165.

RIPP, S., JEGIER, P., BIRMELE, M., JOHNSON, C.M., DAUMER, K.A., GARLAND, J.L., SAYLER, G.S.: Linking bacteriophage infection to quorum sensing signalling and bioluminescent bioreporter monitoring for direct detection of bacterial agents. J. Appl. Microbiol., 100, 2006, 488-499.

SCHUCHAT, A.: Epidemiology of group B streptococcal disease in the United States: shifting paradigms. Clin. Microbiol. Rev., 11, 1998, 497-513.

SIDHU, S.S.: Engineering M13 for phage display. Biomol. Engin., 18, 2001, 57-63.

SMITH, G.P.: Filamentous fusion phage: novel expression vectors that display cloned antigens on the virion surface. Science, 228, 1985, 1315-1317.

STÅLHAMMAR-CARLEMALM, M., STENBERG, L., LINDAHL, G.: Protein Rib: a novel group B streptococcal cell surface protein that confers protective immunity and is expressed by most strains causing invasive infections. J. Exp. Med., 177, 1993, 1593-1603.

STEWART, G.S., JASSIM, S.A., DENYER, S.P., NEWBY, P., LINLEY, K., DHIR, V.K.: The specific and sensitive detection of bacterial pathogens within $4 \mathrm{~h}$ using bacteriophage amplification. J. Appl. Microbiol., 84, 1998, 777-783.

WALDOR, M.K., FRIEDMAN, D.I.: Phage regulatory circuits and virulence gene expression. Curr. Opin. Microbiol., 8, 2005, 459-465.

WANG, L.F., YU, M.: Epitope identification and discovery using phage display libraries: applications in vaccine development and diagnostics. Curr. Drug Targets, 5, 2004, 1-15.

WATSON, B.B., EVELAND, W.C.: The application of the phagefluorescent antiphage staining system in the specific identification of Listeria monocytogenes. I. Species specificity and immunofluorescent sensitivity of Listeria monocytogenes phage observed in smear preparations. J. Infect. Dis., 115, 1965, 363-369.

WILLATS, W.G.T.: Phage display: practicalities and prospects. Plant Mol. Biol., 50, 2002, 837-854.

WINTER, G., GRIFFITHS, A.D., HAWKINS, R.E., HOOGENBOOM, H.R.: Making antibodies by phage display technology. Annu. Rev. Immunol., 12, 1994, 433-455.

WOMMACK, K.E., COLWELL, R.R.: Virioplankton: viruses in aquatic ecosystems. Microbiol. Mol. Biol. Rev., 64, 2000, 69-114. 